\title{
Analisis Nilai Karakter dalam Film Nussa dan Rara Karya Aditya Triantoro
}

\author{
Fanny Rizka Afrilia \\ Program Studi PGSD Universitas PGRI Semarang, fannyafrilia410@gmail.com
}

\begin{abstract}
Abstrak. Penelitian ini dilatar belakangi oleh banyaknya karakter anak yang negatif dan menyimpang yang terjadi di lingkungan sekitar. Oleh karena itu, perlu diberikan media pendidikan yang dapat merubah karakter anak untuk menjadi lebih baik. Media pendidikan tersebut yaitu melalui tayangan televisi seperti film anak-anak yang mendidik. Penelitian ini bertujuan untuk mengetahui nilai karakter dalam film Nussa dan Rara karya Aditya Triantoro. Jenis penelitian ini adalah Kualitatif. Metode pengumpulan data berupa wawancara, dokumentasi, dan simak catat. Data dianalisis dengan mendeskripsikan nilai karakter dalam film Nussa dan Rara karya Aditya Triantoro. Hasil analisis terdapat 18 Nilai Karakter yang muncul pada Film Nussa dan Rara karya Aditya Triantoro seperti nilai karakter religius, jujur, toleransi, disiplin, kerja keras, kreatif, mandiri, demokratis, rasa ingin tahu, semangat kebangsaan, cinta tanah air, menghargai prestasi, bersahabat/komunikatif, cinta damai, gemar membaca, peduli lingkungan peduli sosial, dan tanggung jawab.
\end{abstract}

Kata Kunci: Nilai Karakter, Film Nussa dan Rara.

Abstract. This research is motivated by the many negative and deviant characteristics of children that occur in the surrounding environment. Therefore, it is necessary to provide educational media that can change the character of children for the better. The educational media is through television shows such as educational children's films. This study aims to determine the value of characters in the film Nussa and Rara by Aditya Triantoro. This type of research is qualitative. Data collection methods include interviews, documentation, and note taking. Data were analyzed by describing the character values in the film Nussa and Rara by Aditya Triantoro. The results of the analysis there are 18 Character Values that appear in the Nussa and Rara Films by Aditya Triantoro such as religious character values, honesty, tolerance, discipline, hard work, creative, independent, democratic, curiosity, national spirit, love of the motherland, respect for achievement, friendly / communicative, peace-loving, fond of reading, caring about the environment, social care, and responsibility.

Keywords: Character values, Film Nussa and Rara .

\section{Pendahuluan}

Pendidikan adalah sebuah kebutuhan wajib yang harus dimiliki setiap manusia yang hidup. Pendidikan saat ini sangat pentig bagi manusia karena berpengaruh pada kehidupan sehari-hari. Manusia yang hebat adalah manusia yang tidak pernah melupakan pendidikan. Pendidikan juga merupakan sebuah pondasi bagi negara. Negara Indonesia telah merdeka pada tahun 1945, dan negara kita akan lebih baik lagi jika memajukan kegiatan pendidikan yang berkualitas. Dengan kata lain pendidikan sangat berpengaruh besar bagi negaranya. Negara yang hebat bukan dilihat dari segi 
kemenagan tetapi negara yang hebat dilihat dari mutu pendidikan yang dapat mencetak sumber daya manusia yang hebat, pintar, dan berkarakter.

Pendidikan yang paling utama berasal dari ibu dan lingkungan keluarga. Keluarga yang baik harus bisa menanamkan nilai-nilai pendidikan yang positif. Menurut Poerwadarminta (Kamus Besar Bahasa Indonesia) dalam Syarbini (2017: 71) menjelaskan bahwa secara etimologis keluarga adalah orang-orang yang berada dalam seisi rumah yang sekurang-kurangnya terdiri dari suami, istri, dan anak-anak. Dalam Kamus Besar Bahasa Indonesia, keluarga diartikan dengan satuan kekerabatan yang sangat mendasar dalam masyarakat. Biasanya terdiri dari ibu, bapak, dengan anak-anaknya, atau orang yang seisi rumah yang menjadi tanggung jawabnya. Oleh, karena itu kkeluarga memiliki peranan begitu penting dalam mendidik anak.

Anak adalah karunia yang paling indah bagi orang tua, karena atas izin Allah SWT orang tua dapat memilik anak laki-laki ataupun perempuwan. Orang tua yang baik akan selalu mendidik anaknya dengan hal yang positif. Seorang anak harus dibekali banyak hal dari keluarga terutama ilmu dan tidak lupa dengan agama yang harus selalu tertanam di keluarga. Kebiasaan orang tua akan ditiru anak-anak di rumah. Oleh karena itu, orang tua harus bisa menjadikan dirinya sebagai contoh yang baik.

Pendidikan yang harus ditanamkan anak sejak dini yaitu pendidikan nilai karakter. Menurut Megawati (2004) dalam (Kesuma, Cepi, Permana, 2013: 5) pendidikan karakter adalah sebuah usaha untuk mendidik anak-anak agar dapat mengambil keputusan dengan bijak dan mempraktikannya dalam kehidupan sehari-hari, sehingga mereka dapat memberikan kontribusi yang positif kepada lingkungannya. Membentuk karakter seorang anak harus disertai dengan contoh perilaku yang baik sehingga dapat diteladani oleh anak.

Menurut Daryanto (2013: 47) dalam Novianti dan Mushafanah mengatakan bahwa Pendidikan karakter telah teridentifikasi 18 nilai yang bersumber dari agama, pancasila, budaya, dan tujuan pendidikan nasional, yaitu: (1) Religius, (2) Jujur, (3) Toleransi, (4) Kerja Keras, (5) Kerja Keras, (6) Kreatif, (7) Mandiri, (8) Demokratis, (9) Rasa Ingin Tahu, (10) Semangat Kebangsaan, (11) Cinta Tanah Air, (12) Menghargai Prestasi, (13) Bersahabat/Komunikatif, (14) Cinta Damai, (15) Gemar Membaca, (16) Peduli Lingkungan, (17) Peduli Sosial, (18) Tanggung Jawab. Dari 18 nilai karakter tersebut, diharapkan anak-anak saat ini bisa memiliki karakter tersebut untuk menjadikan dirinya menjadi pribadi yang lebih baik lagi. 
Perkembangan zaman saat ini, membuat orang tua merasa cemas dengan perilaku anak. Kebanyakan anak sekarang lebih menyukai dunia gadget dari pada permainan tradisional. Penggunaan gadget yang berlebihan akan membuat dunia anak berbeda yaitu anak akan merasa selalu puas dengan gadget dari pada harus belajar. Oleh karena itu, orang tua sebagai pengawas utama dalam pendidikan pertama anak harus bisa memilihkan sebuah konten yang termuat dunia pendidikan dan menanamkan sebuah nilai-nilai karakter bila orang tua mampu memberikan sebuah teknologi kepada anak, seperti halnya sebuah film pendidikan.

Permasalahan dalam penelitian ini yaitu peneliti melihat banyaknya perilaku anak yang menyimpang (tidak sesuai aturan) membuat semua orang tua pasti menginginkan anaknya mendapatkan pendidikan yang lebih unggul yang dapat mempengaruhi perubahan anak yang lebih baik. Peneliti merasa perlu adanya media pendidikan yang dapat mendukung dunia anak dalam berperilaku. Peneliti melihat Film Nussa dan Rara merupakan sebuah animasi yang memiliki cerita pada dunia anak-anak dengan penyampaian Bahasa yang mudah dipahami, sebagai sebuah hiburan anak yang menyenangkan, juga terdapat sebuah penanaman nilai-nilai pendidikan yang mnegarahkan ke dalam ajaran agama islam, serta nilai-nilai karakter.

Alasan peneliti memilih film Nussa dan Rara sebagai penelitian skripsi karena film Nussa dan Rara mengandung nilai karakter yang baik untuk diperoleh dan sebagai contoh perilaku baik untuk anak-anak. Film Nussa dan Rara setiap episodenya memiliki alur cerita yang berbeda-beda dan memberikan pesan diakhir cerita. Film Nussa dan Rara menceritakan dua saudara kandung yang hidup bersama dengan kehidupan yang bahagia dan sederhana. Film ini memberikan dunia pendidikan yang membawa tema Islam. Oleh karena itu penting untuk menganaisis film kartun anak yang berjudul Nussa dan Rara untuk mengetahui nilai karakter apa saja yang disampaikan dalam film tersebut sehingga diharapkan dapat memberi contoh dalam berperilaku yang sesuai dengan perkembangan anak.

\section{Metode}

Jenis pendekatan penelitian ini menggunakan penelitian kualitatif dengan metode penelitian deskriptif. Penelitian kualitatif merupakan penelitian berdasarkan data. Penelitian yang dilakukan peneliti yaitu melakukan analisis nilai karakter dalam film Nussa dan Rara karya Aditya Triantoro.

Tempat penelitian yang dilakukan peneliti yaitu menggunakan penelitian non eksperimen, penelitian yang tidak dilakukan di lapangan. Peneliti ingin 
meneliti nilai karakter dalam film Nussa dan Rara dengan narasumber penelitinya adalah kepala sekolah dasar, guru sekolah dasar, orang tua siswa, dan salah satu dosen PGSD UPGRIS.

Sumber data berdasarkan data primer yang berdasarkan film Nussa dan Rara yang diunduh melalui Youtube sedangkan sumber data sekunder berdasarkan hasil wawancara dari kepala sekolah dasar, guru sekolah dasar, orang tua siswa, dan salah satu dosen PGSD UPGRIS. Teknik pengumpulan data yang digunakan untuk memperoleh data yaitu wawancara, dokumentasi, dan simak dan catat. Analisis data dilakukan dengan reduksi data, penyajian data, dan conclusion. Dalam melakukan analisis perlu dilakukan beberapa tahap yaitu (1) menonton film Nussa dan Rara, (2) menganalisis nilai karakter dalam film Nussa dan Rara (3) menyimpulkan hasil analisis nilai karakter dalam film Nussa dan Rara.

\section{Hasil dan Pembahasan}

Hasil dan pembahasan penelitian ini menjelaskan nilai karakter pada film Nussa dan Rara karya Aditya Triantoro. Peneliti memfokuskan pada 18 nilai karakter bangsa diantaranya yaitu (1) religius, (2) jujur, (3) toleransi, (4) disiplin, (5) kerja keras, (6) kreatif, (7) mandiri, (8) demokratis, (9) rasa ingin tahu, (10) semangat kebangsaan, (11) cinta tanah air, (12) menghargai prestasi, (13) bersahabat, (14) cinta damai, (15) gemar membaca, (16) peduli lingkunga,

(17) peduli sosial, (18) tanggung jawab. Dari 18 nilai karakter tersebut, terdapat semua nilai karakter dalam setiap episode film Nussa dan Rara. Setiap episode Nussa dan Rara memiliki perberbedaan dalam waktu setiap volume 1 sampai voulume 7 dan setiap tayangan selalu memberikan pesan diakhir cerita film.

Dari yang peneliti amati selama menonton tayangan film Nussa dan Rarra, peneliti mendapatkan sebuah nilai karakter dari setiap episodenya. Adapun penjelasan episode beserta nilai karakter yang tertulis dibawah ini yaitu :

Tabel 1. Hasil Pengamatan Film Nussa dan Rara

\begin{tabular}{|c|c|c|}
\hline No. & Episode & Nilai Karakter \\
\hline \multirow[t]{2}{*}{1.} & 1. "Tidur Sendiri Gak Takut" & a. Religius \\
\hline & & b. Displin \\
\hline \multirow[t]{2}{*}{2.} & 2. "Dahsyatnya Basmallah" & a. Religius \\
\hline & & b. Gemar Membaca \\
\hline 3. & 3. "Senyum Itu Sedekah" & a. Peduli Sosial \\
\hline
\end{tabular}




\begin{tabular}{cll}
\hline No. & \multicolumn{1}{c}{ Episode } & \multicolumn{1}{c}{ Nilai Karakter } \\
\hline 4. & 4. "Viral, Bersih Kota Kita & a. Rasa Ingin Tahu \\
& Bersih Indonesia" & b. Peduli Lingkungan \\
& & c. Menghargai Prestasi
\end{tabular}

5. 5. "Sudah Adzan Jangan a. Bersahabat/komunikatif Berisik"

6. 6. "Belajar Ikhlas"

a. Cinta Damai

7. 7. "Siapa Kita"

a. Rasa Ingin Tahu

b. Religius

8. 8. "Jangan Boros"

a. Tanggung Jawab

b. Toleransi

9. 9. "Yaah...Hujan!!"

a. Cinta Damai

b. Religius

10. 10. “Kak Nussa”

a. Gemar Membaca

b. Rasa Ingin Tahu

c. Toleransi

11. 11. "Rarra Salit"

a. Religius

b. Disiplin

12. 12. "Tak Bisa Balas"

a. Tanggung Jawab

b. Mandiri

c. Kreatif

13. 13. "Jangan Kalah Sama

a. Jujur Syetan"

b. Toleransi

14. 14. "Nussa Bisa"

a. Kerja Keras

15. 15. "Libur...Jangan Lalai"

a. Demokrasi

16. 16. "Jadi Suka Sayur"

a. Bersahabat/komunikatif

17. 17. "Latihan Puasa"

a. Rasa Ingin Tahu

b. Bersahabat/komunikatif

18. 18. "Baik Itu Mudah"

a. Menghargai Prestasi

b. Kerja Keras

c. Kreatif

19. 19. "Merdeka"

a. Semangat Kebangsaan

b. Cinta Tanah Air

20. 20. “Teman Baru Rarra”

a. Gemar Membaca 
Hasil pengumpulan data dari studi dokumentasi, wawancara, dan simak dan catat menunjukkan bahwa Film Nussa dan Rara memiliki nilai karakter yang tertanam dalam setiap episode yang berbeda. Nilai karakter yang terdapat dalam setiap episode memiliki nilai khusus dalam tayangan yang berbeda. Akan tetapi, kebanyakan tayangan yang muncul memiliki nilai religius yang tinggi. Film Nussa dan Rara merupakan film yang mengandung nilai Islami. Film ini sangat layak untuk anak-anak. Karakter pada pemain film juga memberikan dampak positif bagi penonton. Film ini baru saja dibuat oleh anak bangsa Indonesia. Awal kemunculan Film Nussa dan Rara mendapatkan antusias yang sangat luar biasa dari masyarakat Indonesia karena masyarakat merasa terbantu dengan adanya Film yang memiliki pengetahuan agama yang baik.

Pengumpulan data yang dilakukan peneliti yaitu dengan cara wawancara kepada 4 narasumber yang terpilih yaitu kepala sekolah dasar, guru sekolah dasar, orang tua siswa, dan salah satu dosen PGSD UPGRIS. Peneliti melaksanakan wawancara dengan memberikan beberapa pertanyaan seputar Film Kartun Anak. Dari ke empat narasumber memberikan pendapat yang sangat baik. Semua narasumber menyukai Film kartun untuk anak-anak karena dari sebuah film anak dapat meniru perilaku yang baik, asalkan film yang dipilih juga memberikan pengetahuan, pengalaman, dan pembelajaran yang baik bagi anak. Contohnya pada Film Nussa dan Rara pada episode "Senyum Itu Sedekah", memiliki cara bagaimana anak bisa menjadi orang baik, bisa mengetahui apa itu bersedekah, dan bagaimana cara bersedekah yang baik.

Berdasarkan tabel 1, Hasil Pengamatan Film Nussa dan Rara menunjukkan nilai karakter pada setiap episode yang sudah tertanamkan dnegan baik oleh pemain Film Nussa dan Rara. Hal tersebut diperoleh dari catatan peneliti yang melihat karakter pada pemain Film Nussa dan Rara. Nilai Karakter dalam setiap episode berbeda, akan tetapi dari semua episode memiliki nilai religius yaitu sikap dan perilaku yang patuh dalam melaksanakan ajaran agama yang dianutnya, toleran terhadap pelaksanaan ibdaah orang lain, serta hidup rukun dengan pemeluk agama lain. 


\section{Simpulan}

Berdasarkan hasil penelitian dalam olah data dan pembahasan yang telah diuraikan oleh peneliti, maka dapat disimpulkam bahwa Film Nussa dan Rara setiap episodenya memiliki nilai karakter yang berbeda dan ada juga yang sama. Film Nussa dan Rara mempunyai 18 nilai karakter yang dimiliki oleh pemain Nussa dan Rara yaitu seperti Nussa, Rarra, Ibu Nussa, Sahabat Nussa dan Rara, dan sebagainya. Peneliti memfokuskan pada 18 nilai karakter bangsa diantaranya yaitu (1) religius, (2) jujur, (3) toleransi, (4) disiplin, (5) kerja keras, (6) kreatif, (7) mandiri, (8) demokratis, (9) rasa ingin tahu, (10) semangat kebangsaan, (11) cinta tanah air, (12) menghargai prestasi, (13) bersahabat, (14) cinta damai, (15) gemar membaca, (16) peduli lingkunga, (17) peduli sosial, (18) tanggung jawab. Sesuai dengan temanya yang bernuansa Islami, Film Nussa dan Rara memiliki nilai karakter religius yang setiap episodenya selalu ada.

\section{Daftar Pustaka}

Daryanto, dan Darmiatun. 2013. Pendidikan Karakter di Sekolah. Yogyakarta: Gava Media.

Eko, Jalil, dan Faisol. 2019. Nilai-Nilai Pendidikan Islam Dalam Film Animasi Nussa Dan Rara Karya Aditya Triantoro. Jurnal. Malang.

Novianti, dan Mushafanah. 2019. Analisis Nilai Karakter Pada Siswa Sekolah Adiwiyata SD Negeri Pleburan 04 Semarang. Jurnal. Semarang.

Syarbini, Amirulloh. 2017. Pendidikan Karakter Berbasis Keluarga. Jogjakarta: AR-Ruzz Media. 